\title{
Estimation of quantitative descriptors of northeastern Mediterranean karst behavior: multiparametric study and local validation of the Siou-Blanc massif (Toulon, France)
}

\author{
Stéphane Binet \& Jacques Mudry \& Catherine Bertrand \& Yves Guglielmi \& René Cova \\ S. Binet ()): J. Mudry : C. Bertrand EA2642 Géosciences, Déformation, Ecoulement, Transfert, Université of Franche- \\ Comté, 16 route de Gray, 25030, Besancon, France e-mail: stephane.binet@univ-fcomte.fr e-mail: jacques.mudry@univ- \\ fcomte.fr e-mail: Catherine.Bertrand@ univ-fcomte.fr Y. Guglielmi Géosciences Azur, Centre National de la Recherche \\ Scientifique, Université Nice Sophia-Antipolis, 250 rue Albert Einstein, 06560, Valbonne, France e-mail: \\ guglielmi@geoazur.fr R. Cova Direction départementale de l'Agriculture et de la Forêst du Var, 80 avenue Paul Arène, \\ 83300, Draguignan, France
}

\begin{abstract}
:
Key parameters controlling the recharge and behavior of Mediterranean karsts were selected in order to make a quantitative description of northeastern Mediterranean karsts on a regional scale. The methodology was applied to an actual karstic aquifer on the Siou-Blanc Plateau (France). For the recharge study, it was observed that the average yearly rainfall value and $\delta_{18} \mathrm{O}$ measurements in springs can be considered as good descriptors of climatic variations observed in the Mediterranean area.

They can be used to estimate the intake area and the infiltration coefficient. A comparison with a numerical (double permeability) flow model (MODFLOW) on the Siou-Blanc karst improves these exponential relations between effective rainfall and $\delta_{18} \mathrm{O}$ measurements. Infiltrated water, which flows though different rock types, induces contrasts in the water chemistry. An instantaneous physical and chemical analysis of all the springs of the Siou-Blanc aquifer displays the same expected functioning and variations as had been forecast using the conceptual scheme. Thus, it can be applied to wide areas associated with a northeastern Mediterranean climate for a first approach of a karst study; such a model enables a useful estimation of recharge and behavior with few simple data.
\end{abstract}

Keywords Karst . Mediterranean climate . Groundwater recharge . Water chemistry . Toulon

\section{Introduction}

Over a wide area, the Mediterranean hydrogeological context involves similar characteristics: (1) similar geologic alpine structures, (2) typical low vegetation prevailing on the carbonate substratum, (3) a dry season with scarce but intense rainfall episodes (700-800 mm/year), (4) mountainous terrain inducing rainfall that increases rapidly with elevation. Karst aquifers are subjected to parameters that are fairly similar, therefore the determination of relevant factors could enable a conceptual model to be built of the northeastern Mediterranean karst. Among a broad choice of parameters (input and output), the problem is to choose the relevant parameters. The choice of parameters is realized with the aim of characterizing karst recharge and behavior. The study aims to show how simple climatic parameters and water chemistry measurements of karst springs contribute to a quantitative estimate of northeastern Mediterranean karst recharge, behavior, and residence time. Each estimation will be tested on a well-constrained Mediterranean karst: the Siou-Blanc karst aquifer, France. The infiltration coefficient and its spatial variability were defined with numerical modeling, calibrated with spring hydrographs and $\delta_{18} \mathrm{O}$ (stable isotope of oxygen) measurements. Fast/ slow infiltration and rock/water interactions are discriminated from the descriptor variations through a statistical comparison.

\section{Construction of a conceptual model of the Karst behavior}

The model was based on a regional scale (Fig. 1), with data from Bakalowicz 1979; Laty 1981; Vernet and Vernet 1981; Mudry 1987; Puig 1987; Lastennet 1994; Chalumeau 2000; Emily 2000; Plagnes 2000; Reynaud 2000. These studies involved multi-parameter analyses, with recording of many input/output data, topographic data (elevation, latitude, slope, soil type, etc.), climatic parameters (air temperature, rainfall values, sun radiation, etc.), and output data (spring outflows, water chemistry, isotopes measurements, etc.). This model selects relevant parameters, with few measurements, to describe the karst functioning. The selection of the key parameters was realized with intercorrelations which show redundancy between recorded parameters. The functioning model was built in three different steps: (1) infiltration haracterization, (2) understanding fluid/rock interactions, and (3) residence time estimation. The first step 
involves delimiting the intake area to attain a hydrogeological water balance, and then estimating the effective rainfall. Comparison of temperature and rainfall gradients versus elevation (Mudry 1987; Puig 1987; Lastennet 1994; Andreo 1996; Fairchild et al. 2000; Reynaud 2000; Table 1) shows that the spatial variability around the Mediterranean Sea can be wide at about one order of magnitude.

These gradients improve the water balance estimation on a regional scale because they take better account of both a contrasted elevation and a contrasted Mediterranean climate. As a matter of fact, it appears that the rainfall value, temperature and elevation are correlated to each other with gradients. So only one of these values can be a relevant factor of the peculiarities of the area. Another relevant factor, correlated with climatic factors, is the $\delta_{18} \mathrm{O}$ measurement of spring water which gives us information about the recharge area that supplements climatic observation (this concept will be developed later in the paper).

The second step is a quantification of infiltrated water (volume) and flow paths using water chemical measurements (Bakalowicz 1995; White 2002). Measurements of major ion concentrations, $\delta_{18} \mathrm{O}$ and the few data about the soil thickness and exokarstification, enable an estimate to be derived for effective infiltration and for flow paths.

The third step consists of isolating the two major drainage components in karst aquifers - the quick infiltration component that is flowing through conduits with a low chemical content (Mudry et al. 1994; Martin and Dean 2001), as opposed to the slow infiltration component, flowing though fractured rocks with a higher chemical content (Mudry 1987). The flows in saturated or unsaturated zones can be marked with $\delta_{13} \mathrm{C}$ (stable isotope of carbon) measurements (Emblanch, 1997). The epikarstic aquifer can have a storage role, as demonstrated by $\delta_{18} \mathrm{O}$ data during a flood (Perrin et al. 2003). Isotopic measurements like tritium or oxygen isotopes provide information about residence time that can be quantified with a simple model Blavoux and Letolle 1995). Other residence time markers are magnesium, 13-carbon (Mudry et al. 2002) and Total Organic Carbon (TOC; Celle-Jeanton et al. 2003). The concentrations of these elements in water evolve with time (Batiot 2002; Batiot et al. 2003); the measurement is simpler than isotopic measurements and enables inter-area comparison.

Thus, the tritium repartition in the air is complex and evolves in time (Fontes 1976; Blavoux and Letolle 1995); therefore, inter-area comparison, with measurements taken at different times, will not give regional information.

The regional relationships between rainfall, infiltration, karst functioning, and residence time presented in the first part of the study show that they are all connected to each other. The conceptual diagram (Fig. 2) shows the water flow from rainfall to spring discharge, the principal steps which influence the water hemistry, and the descriptors which characterize the flow in a northeastern Mediterranean karst aquifer. The next quantitative approach will define the forecasted value of the relevant parameters, with statistical correlations between the key parameters.

\section{Methodology to test the conceptual model: application to the Siou-Blanc Karst aquifer The Siou-Blanc Plateau}

The Siou-Blanc massif is a limestone plateau, 826 ( $\mathrm{m}$ a.s.l.) at its highest point in the Toulon hinterland (Var region). It is bounded by the Gapeau (to the northeast) and the Reppe (to the west) valleys. The mountain range alignment (Coudon, Combes, Caumes) determines the southern boundary of this massif. It is covered by low vegetation and is subjected to a typical Mediterranean climate. The study area is about 30 $\mathrm{km}$ from the Mediterranean Sea. The karst, about $110 \mathrm{~km} 2$ wide, is drained by springs described in Table 2 . Tracer tests have confirmed the boundaries of some sub-systems (Fig. 3 and Table 3), but water balance is deficient and it seems that a significant part of water flows under the sea in the "Rade de Toulon" through a submarine spring (Lamarque and Maurel 2000).

The general structure corresponds to limestone and dolomite aquifers that belong to the calcareous Provence region (Blanc et al. 1974) outcropping over the Triassic evaporites (Fig. 3). The stratigraphic series ranges from Muschelkalk to Turonian. The tectonic partition of the Siou-Blanc Plateau divides it into three units-Morieres, Ragas, and Tete du Cade-which give it an internally complex structure (Gouvernet 1963, 1969).

\section{Adopted methodology}

An 'instantaneous' physical and chemical analysis of all the springs that drain the Siou-Blanc aquifer was performed during a long, low groundwater-level period in June 2002 (810 $\mathrm{mm}$ of rain fell in 2001, but the first 6 months of 2002 were without any effective rain). The major ion composition of springs (Table 2) were compared with the conceptual model of karst functioning. Observing concentration variations of appropriate factors defined in the conceptual model would permit the testing of the previous descriptors. 
The analyses were undertaken at the Geosciences Laboratory (University of Franche-Comté). Cation measurements were made with the atomic absorption spectrophotometer PerkinElmer A analyst 100 and the anion measurement with a high-pressure ionic chromatograph Dionex DX 100 (precision is about 5\% maximum, according to the dilution coefficient). Bicarbonate was measured volumetrically. The stable isotope of oxygen, $\delta_{18} \mathrm{O}$, was determined with a mass spectrometer MAT 250 Hausverfahren $\left( \pm 0.15 \delta_{18} \mathrm{O}\right)$ by Hydroisotop $\mathrm{GmbH}$; the unit of measurement corresponds to a normalized value referred to as the seawater value. The TOC was analyzed with a Bioritech TOC analyzer $( \pm 0.05 \mathrm{mg} / \mathrm{L})$ by the University of Avignon. Flow rate measurements at the Rampins spring and rainfall measurements on the Pilon Saint Clement Massif were collected by Chanut (1976). These measurements enable a comparison of actual data with regional quantification of flow using two approaches: (1) numerical calculation to test repartition of flow with elevation, and (2) statistical test to improve the chemical descriptors choice of flow paths, and using organic carbon to study an actual residence time problem.

\section{Aquifer recharge: a quantitative approach In situ recharge assessment}

A graph displaying evolution of infiltration in the area (Fig. 4) was derived from data from Mont Ventoux in the Vaucluse region (Puig 1987; Emblanch et al. 1998), Mont Vial and Nice ranges (Maritime Alps; Emily 2000 and Reynaud 2000), from eight weather stations in the Bouches-du-Rhône region (Vernet and Vernet 1981), seven areas in the Var region (Cova and Durozoy 1980), four sites in the Hérault region (Laty 1981) and one site in Malaga, Spain (Andreo 1996).

As a link had been observed between rainfall value, elevation, and temperature (Table 1), the average yearly rainfall value should characterize the climatic variations from one place to another. The average yearly rainfall value, which is easy to obtain, incorporates variations of several parameters (temperature, altitude, watershed exposition) which are necessary for infiltration estimation.

The infiltration coefficient is a descriptor that enables karst systems to be compared. It corresponds to the ratio of infiltrated water volume against rainfall volume and quantifies the effect of evapotranspiration.

The coefficients used here are all derived from rainfall/ flow rate studies. A graph of the log of average yearly rainfall value versus infiltration coefficient (Fig. 4) shows a point repartition between two extreme curves. The dispersion of the infiltration coefficient (intercept to origin) is caused by the soil type. Gdalia (1980) had used analytic modeling on several Mediterranean karsts to attest that the soil thickness is one of the most relevant inter-area infiltration parameters. The karst aquifers, situated near the highest curve (high infiltration coefficient), display important exokarstic forms, with thin soils and no important runoff.

In the opposite case, the karsts with low infiltration coefficients present a situation where soil with high vegetative content covers the epikarst fractures. The inter-annual climatic variations are represented by the lines drawn on Fig. 4. This graph is a tool to estimate infiltration with yearly rainfall values and few observed data.

Another parameter for estimating the infiltration water volume is $\delta_{18} \mathrm{O}$ measurements during low rainfall periods (Blavoux and Mudry 1990). $\delta_{18 \mathrm{O}}$, which is thermodependent and stable during infiltration time, is an excellent infiltration tracer (Razafindrakoto 1988).

Guglielmi et al. (1998) give a relationship between $\delta_{18} \mathrm{O}$ and recharge altitude (Table 1) that is valid for Southeastern France. As infiltration is related to climate and soil type, and as it is one of the more important parameters used for hydrogeological studies, a scatterplot of yearly effective rainfall and $\delta_{18} \mathrm{O}$ easurements was prepared (Fig. 5). The volume of infiltration water estimate can be confirmed by a comparison between these two different approaches.

$\delta_{18} \mathrm{O}$ is controlled by climatic conditions and evapotranspiration (Fontes 1976). Locally, the origin of air masses, seasonal variations, and local microclimatic difference between sunny or shady mountain slopes influence the $\delta_{18} \mathrm{O}$ rain content (Guglielmi et al. 1998). However, $\delta_{18} \mathrm{O}$ remains an interesting descriptor of infiltration. Taking into account the low groundwater level, the correlation (Fig. 5) between $\delta_{18} \mathrm{O}$ measurements and effective rainfall is another tool for flux estimation. On this scale, the isotopic gradient is marked by the high contrast in elevation, which takes precedence over the local variability (Guglielmi et al. 1998). The $\delta_{18} \mathrm{O}$ values represent recharge by infiltration only if the measurements have been taken during low groundwaterlevel periods. The $\delta_{18} \mathrm{O}$ values during flood periods are controlled by more complex phenomena not described here, like partitioning evolution during the flood (Vandenschrick et al. 2002; Lee and Krothe 2001). This correlation is an interpolation between data from Nice to Malaga, so one can consider that these relations are valid on the northeastern Mediterranean karsts. Estimation of the rainfall value and recharge altitude gradients gives a better understanding of rainfall and integrates the spatial variability of a massif. Thus, the volume of infiltrated water can be estimated with a precision of about 
$\pm 10 \%$ (calculated with residue of the linear correlation in Fig. 4) and this resolution enables inter-annual variations and inter-area differences to be distinguished.

\section{Numerical parametric study of recharge variation}

\section{Objectives}

Yearly rainfall values and $\delta_{18} \mathrm{O}$ values, used to describe infiltration, record the influence of elevation in the estimation of the volume of water input in the karst. The non-linear correlation between these parameters and infiltrated water suggests that an infiltration gradient exists with the elevation. A numerical model of a karstic spring flow was set up in order to estimate the infiltration coefficient during a flood. This method should take account of spatial variability, and allow for the study of the relative importance of a gradient of infiltration water versus elevation. Thus, the variability observed in Fig. 4 can be discussed.

\section{Method}

The numerical model applies to the Pilon Saint Clement area (Fig. 3) studied by Chanut (1976). It is a simple hydrogeological sub-system which presents an interesting elevation variation (ranging between 350 and $700 \mathrm{~m}$ a.s.l.) within the watershed. This elevation can be considered as representative of the average elevation of the Mediterranean recharge area. The geological structure is a syncline and the springs are located along the watershed boundary, emerging on the impermeable layer. Rainfall is the only input in the hydrogeologic system. Spring outflow and rainfall were monitored for 4 years between 1974 and 1976, comprising three average years and one exceptionally rainy year (1976). The recharge area of the three springs draining the massif will be defined with the MODFLOW model. The outflow of the Rampins spring (spring 3 in Fig. 6a) ranges between 4 and 7,500 L/s. Numerical tests were undertaken with MODFLOW (McDonald and Harbaugh 1988), which simulates underground water flows using a finite difference method in a porous saturated media (Scanlon et al. 2003). The model enables the assessment of infiltration with a rainfall value and outflow data. Infiltration flow rate is spatialized with the three-dimensional calculation. Tests aim to show and quantify the connection between elevation and increase in infiltration.

Many parametric tests were performed to adjust the flow in the massif with the measured flows at the springs. The mountain is cut in vertical blocks with a permeability of $10-6 \mathrm{~m} / \mathrm{s}$ and an effective porosity of $0.05 \%$, separated by fractures. Fracture permeability is represented by a $1 \mathrm{~m} / \mathrm{s}$ permeability and an effective porosity of $0.01 \%$, and assimilated to vertical continuous layers with a width of $10 \mathrm{~m}$ (Mangin 1975 and Eisenlohr 1997). The density of fractures and their orientation were estimated with the geological setting (Fig. 6).

The spring is modeled using a drain boundary condition, equivalent to the cave observed at the site (Dufresne and Drake 1999). The recharge area of the Rampins spring is defined with a steady-state calculation. The limits of the recharge area can be precisely defined (Fig. 6) with a fixed geometry, and the discharges during low rainfall periods can be measured at springs 1,2, and 3. This model does not aim to demonstrate flow paths in a karst system, but it enables the determination of a recharge area with such a geometry and is, therefore, appropriate for the Rampins spring. Evapotranspiration estimates can then be tested in this recharge area.

\section{Parametric tests on infiltration}

The main objective of the parametric tests is to test which parameters (using recorded data) influence the intra-area variability in infiltration and rainfall (shown in Fig. 4) in the Pilon Saint Clement area. The main factors of the variability between infiltration ratio and yearly rain value seem to be elevation and interannual climatic variations, and two types of parametric analysis were undertaken to test and compare these observations. First, on a yearly scale, several infiltration coefficients were calculated for 4 years, where rainfall conditions were different. Only climatic conditions were varying. The first year was the reference calculation and the three other years were used to study the annual variability. The will show if the yearly rainfall value correctly describes these variations. It will confirm that the line, in Fig. 3, represents intraarea variations. Secondly, with a rainfall scale in the order of a few days, applied to the numerical model, several gradients of evapotranspiration were applied to test elevation influence on infiltrated water volume. The first calculation was undertaken without an infiltration gradient value to calibrate the model and estimate the average infiltration coefficient (Fig. 6b). Then, the same calculation was undertaken with different infiltration gradients applied to water input. This test does not significantly modify the numerical calibration of water volume. The second calibration step involves parametric tests of the repartition of infiltrated volumes in space in order to compare its effects on calculated $\delta_{18} \mathrm{O}$ at the spring. The $\delta_{18} \mathrm{O}$ 
variability is linked to elevation variability on the recharge area and an actual gradient was defined with field data $\left(\delta_{18} \mathrm{O}=-0.0055 \times\right.$ elevation $-4 ; \mathrm{n}=12, \mathrm{r}=$ correlation coefficient $\left.=-0.96\right)$. An increase of infiltration coefficient versus elevation means that the infiltrated water originates from the highest elevation area, which depletes the $\delta_{18} \mathrm{O}$ value. The calculated $\delta_{18} \mathrm{O}$ value at the Rampins spring incorporates a mixture of waters coming from different elevations with different $\delta_{18} \mathrm{O}$ values (Table 4). The $\delta_{18} \mathrm{O}$ adjustment is realized with a comparison of $\delta_{18} \mathrm{O}$ measurements and calculations. It will show if the rainfall value gradient and the $\delta_{18} \mathrm{O}$ measurements, estimated with the conceptual model, correctly describes the influence of elevation.

\section{Results}

The results of parametric tests on a yearly scale (Fig. 4) show that under various yearly climatic conditions, the evolution of infiltration coefficient versus yearly rainfall value can be fitted with this logarithmic statistic expression:

Infiltration coefficient 1/40:47_lnðyearly rainfallP_2:85; $r^{1 / 4}$ 0:96; $n$ 1/4 4:

This regression supplements the regional quantitative model and proves, by calculation, that the line in the graph describes intra-area variations mainly linked to soil effects. With the rainfall scale in the order of weeks and internal parameters fixed, for an optimum calibration of the water volume mobilized during a flood without elevation gradient, the average infiltration coefficient needs to be fixed at $0.21 \%$ (Fig. 6b). This calibration establishes the gradient of the infiltration coefficient as being equal to $10 \mathrm{~mm}$ per $100 \mathrm{~m}$, including the rainfall gradient monitored at the site $(7 \mathrm{~mm}$ per $100 \mathrm{~m})$.

Now, estimation of the infiltrated water volume is undertaken with the regional model to compare both approaches. The measurements of the Siou-Blanc $\delta_{18} \mathrm{O}$ values range between -5.8 and $-7.5 \%$ and the mean is about $-6.58 \% \delta_{18} \mathrm{O}$. The $\delta_{18} \mathrm{O}$ variability of the measurements can be used to estimate (with Fig. 5 ) an infiltration gradient with elevation. A gradient of $11 \mathrm{~mm}$ per $100 \mathrm{~m}$ was obtained for an average effective rainfall of $300 \mathrm{~mm}$.

These gradients, estimated with a numeric calculation and the conceptual model, give a value of $10 \mathrm{~mm}$ per $100 \mathrm{~m}$, which is coherent and proves the existence of an infiltration gradient independent of the rainfall value gradient $(7 \mathrm{~mm}$ per $100 \mathrm{~m})$.

The comparison between the regional $\delta_{18} \mathrm{O}$ approach and the numerical approach, calibrated with local measurements, confirms the importance of elevation in assessing the infiltration coefficient under a Mediterranean climate. The numerical approach enables assessment of infiltrated water on an area with an excellent resolution, since the exact spatial variability is taken into account.

Here, it was proved that the regional model, with $\delta_{18} \mathrm{O}$ gradient, is a good method of calibrating infiltration using a numerical modeling approach. The calibration of the gradient has the same precision, whether undertaken with numerous meteorological data or with the $\delta_{18} \mathrm{O}$ gradient, but the second is easier to obtain. Thus, water chemistry is a calibration tool for flow modeling.

\section{Behavior based on chemical descriptors Karst water content of Mediterranean karst systems and water-rock interactions}

Water chemistry variation in springs of the Mediterranean karst aquifer is mainly controlled by lithology (Mudry 1987). Rainwater has a lower concentration compared to spring water, and human-induced pollution (for example $\mathrm{NO}_{3}-$ ) is generally low in a karst area, which often constitutes the mountainous areas of the Mediterranean region. Water chemistry provides, then, a set of natural tracers that enables flow paths to be identified, using a lithologic and chemical comparison. Major ions $\mathrm{Mg}_{2+}$,

$\mathrm{Ca}_{2+}, \mathrm{HCO}_{3}-, \mathrm{SO}_{4} 2-$ and $\mathrm{Cl}$ - concentrations are controlled by dolomite, calcite and evaporitic minerals. A threecomponent

diagram of the chemical ratios ( $\left.\mathrm{SO}_{4} 2_{-}+\mathrm{Cl}-\right) / \mathrm{HCO}_{3}-$ and $\mathrm{Mg}_{2} / \mathrm{Ca}_{2}$ variations (Fig. 7) was built, using

data from various karst aquifers of the Mediterranean area. The clusters that represent the aquifer lithology were defined means of small springs with well-known water pathways. The measured ratio shows (1) the preferential flow path, and (2) an intermediate value of a mixture of different waters. This scattergram is useful in collecting information from inside the system. The chemistry can reveal structural elements by comparison of the geological map and the chemical data. For example, an indication of the location of evaporites provides information on the location of the bottom of the aquifer. The variability caused by the variation of residence time is tiny compared to inter-area variability. Residence time increases the water concentrations but does not significantly affect the ratio at this scale, as illustrated in the chemographs of a karst spring in Fig. 7. 


\section{Statistical test applied on Siou-Blanc}

In the Siou-Blanc area, a principal component analysis (PCA) was undertaken on chemical data to test the factors that control the chemical water composition (Olivier 1997; Lopez-Chicano et al. 2001) and validate the rock clusters presented in Fig. 8. PCA validates the choice of descriptive parameters. This classic hydrogeological method displays correlations between variables, placing the factors responsible for observed variations in hierarchical order. Thirty-five samples and 15 variables were used. The three major factor axes were studied. The variance explained by the two major factors is high (49\%) and shows that the lithology explains the major ion scaling. The ions used to describe flow paths are improved by PCA; however, other processes such as anthropic pollution, control a part of the variations (axis 2). For the particular case of $\mathrm{Mg}_{2+}$, its slow dissolution kinetics and its presence in dolomitic rocks creates confusion between residence time and presence of dolomite. The other descriptors of the PCA, like TOC, are not sufficient for differentiating an axis of residence time and an axis of presence of dolomite. However, residence time effect on chemical acquisition is statistically less important than rock mineralogy. Thus, axis 3 mainly represents the variations between limestone and dolomite interaction. The chemical measurements of the Siou-Blanc karst are plotted in Fig. 8 and they fit with the regional forecast.

The regional clusters enable reference water contents to be correlated to lithology. Thus, the ratio $\mathrm{Mg}_{2+} / \mathrm{Ca}_{2}+$ evolves from $0.015( \pm 0.005)$ in a limestone rock to $0.5( \pm 0.1)$ in a $100 \%$ dolomitic rock. The $\left(\mathrm{SO}_{4} 2-+\mathrm{Cl}-\right) / \mathrm{HCO}_{3}-$ variations scale from $0.03( \pm 0.005)$ in a non-evaporitic rock, to $50( \pm 15)$ in halite. The Siou-Blanc test improves the quality of these ratios for describing water content variations. The data of this area are well distributed between these clusters and enable water types with very similar flow paths to be distinguished.

\section{Estimation of the residence time: An interesting descriptor: total organic carbon (TOC)}

When the dolomite proportion remains constant (within the same lithologic formation), the $\mathrm{Mg}_{2+}$ concentration increases with residence time (Blavoux and Mudry 1983). Another interesting tracer of the residence time is the total organic carbon (TOC), especially for short residence times (Batiot et al. 2003). Water dissolves TOC in the soil cover. It is then oxidized in the unsaturated and saturated zones by bacterial activities (Emblanch et al. 1998). The TOC measurements, in all the springs of a given area, can give information about the relative residence time of spring water (Batiot et al. 2003). Compared to an isotopic marker of the residence time, the TOC records the very fast infiltration; in contrast, magnesium content records long residence time. The evolution in time of these elements is always observed, but the initial concentration is variable, meaning that regional correlation is not possible.

\section{TOC contents on the Siou-Blanc springs}

Total organic carbon (TOC) and $\mathrm{Mg}_{2+}$ concentration variations were compared (Fig. 9) for the springs draining the Siou-Blanc karst. The decrease of TOC is correlated to the increase of the magnesium content and with the remoteness of the spring from its mean infiltration zone (cross section, Fig. 9b). These five springs drain the same aquifer water coming from the Siou-Blanc Plateau. The $\delta_{18} \mathrm{O}$ values are similar for these five springs $\left(-6.5 \delta_{18} \mathrm{O} \%{ }_{0} \pm 0.5\right)$ and prove that the water recharge area of these five springs is the same. Tracer tests have confirmed that during low groundwater flow, the greater the infiltration zone, the greater the residence time (Table 3). All these data explain the decrease of TOC compared to the increase of magnesium and are linked to increasing residence time. Experiments with tracer tests yield interesting results used to calibrate the TOC decreases under a given climate (Fig. 9a). TOC, as a residence time marker, has excellent potential in work associated with short residence time and may quantify average residence time of water of this system.

\section{Discussion: relevance of the selected parameters}

The parameters used to describe the Mediterranean karst aquifers are climatic data, major ions, $\delta_{18} \mathrm{O}$ and TOC measurements. The major ions are compared on all the Mediterranean area samples. As the climate is similar for all of them, we can estimate that dissolution kinetics is fairly similar, and concentration has the same order of magnitude. Nevertheless, as chemical concentrations in rainwaters are lower than spring water concentrations by about two orders of magnitude, variations in water chemistry observed in the rainwater measurements were discounted.

The yearly mean rainfall value can be discussed if it is a parameter used for the estimation of infiltration. In a very irregular climatic area characterized by intense and irregular rainfall, yearly parameters are not very 
appropriate. However, yearly mean rainfall was used in this study due to the following advantages: (1) it is an easy access parameter, which indirectly describes elevation, exposition, and temperature variations; (2) it is a simple means for describing the climatic difference between waters in Mediterranean aquifers. The dispersion observed in Fig. 4 can be explained by a complex interaction between soil, slope, and rock type (limestone or dolomite) that cannot be quantified with the presented descriptors.

The use of $\delta_{18} \mathrm{O}$ measurements to estimate recharge needs care. Since $\delta_{18} \mathrm{O}$ water content is a function of temperature on the infiltration area, and of the rainfall intensity, a correlation of $\delta_{18} \mathrm{O}$ with the effective rainfall value requires several precautions. Thus, $\delta_{18} \mathrm{O}$ values must be measured during a long, lowgroundwater period, in order to be representative of evaporation in the average infiltration zone.

\section{Conclusion}

The model, built and tested here, provides some methods of quantifying the recharge and functioning of a Mediterranean karst aquifer using water chemistry and few meteorological data. One of the strong features of water chemistry data in this study is the possibility of comparing different areas. This work proves that water chemistry is controlled by three mechanisms: infiltration, geology an residence time. The dynamics of these mechanisms is similar over the whole Mediterranean climatic area. One can, thus, realize a scalechange and build a regional conceptual model with quantitative data to allow the use of this quantitative model over the whole area. This model is appropriate to the northern part of the Mediterranean area (from Malaga to Nice). For a first approach to studying an aquifer, applying this model requires few data and technical instrumentation and can thus be easily carried out. The chemical measurements give this model an interesting sense of the parameters in relation to the topography. The precision of the quantitative approach of this model enables water budget and water flow studies to be undertaken, which are useful for calibrating a numerical flow model or evaluating water supply in a Mediterranean karst. This model can be improved by including the evolution of water chemistry over time at the main spring outlet of the karst study area, thereby integrating a time dimension within this spatial approach.

Acknowledgements We sincerely acknowledge P. Maurel and T. Lamarque and S. Duncan for improving the English language.

\section{References}

Andreo B (1996) Estudio hidrogeológico de los mármoles alpujárrides de las Sierras Blanca y Mijas (Hydrogeological study of alpujárrides marbles of the Blanca and Mijas mountain ranges). PhD Thesis, University of Granada, Spain

Bakalowicz M (1979) Contribution de la géochimie des eaux à la connaissance de l'aquifère karstique et de la karstification (Contribution of geochemistry of water to the knowledge of karstic aquifers and karstification). PhD Thesis, University Pierre et Marie Curie, Paris, France

Bakalowicz M (1995) La zone d'infiltration des aquifères karstique: méthodes d'étude. Structure et fonctionnement (Infiltration area of karst aquifers: methods of study, structure and behavior). Hydrogéologie 4:3-21

Batiot C (2002) Étude expérimentale du cycle du carbone en régions karstiques. Apport du carbone organique et du carbone minéral à la connaissance hydrogéologique des systèmes. Sites expérimentaux de Vaucluse, Jura, Larzac, Région nordmontpelliéraine, Nerja (Espagne) (Experimental study of carbon cycle in karstic areas. Contribution of organic carbon and mineral carbon to the knowledge of hydrogeology. Experimental sites of Vaucluse, the Jura, Larzac, north-Montpellier region, Nerja, Spain) PhD Thesis, University of Avignon et des Pays de Vaucluse, France

Batiot C, Emblanch C, Blavoux B (2003) Carbone organique total (COT) et magnésium $\left(\mathrm{Mg}_{2+}\right)$ : deux traceurs complémentaires du temps de séjour dans l'aquifère karstique (Total organic carbon (TOC) and magnesium ( $\left.\mathrm{Mg}_{2+}\right)$ : two complementary tracers of residence time in the karstic aquifer). C R Geosci 335:205-214

Blanc JJ, Caron JP, Choquet C, Gouvernet C, Guieu G, Mennessier G, Nahon D, Philip J, Rouire J, Tempier C (1974) Carte géologique de Cuers et notice au 1/50000eme (Geological map of Cuers with explanatory note). Bureau de Recherches Géologique et Minières, Orléans

Blavoux B, Letolle R (1995) Apports des techniques isotopiques à la connaissance des eaux souterraines (Contribution of isotopic techniques to the knowledge of groundwaters). Géochronique 54:4-8

Blavoux B, Mudry J (1983) Séparation des composantes de l'écoulement d'un exutoire karstique à l'aide des méthodes physico-chimiques (Separation of flow components in a karstic discharge system using physical and chemical methods). Hydrogéologie 4:269-278

Blavoux B, Mudry J (1990) Les teneurs en oxygène 18 en fonction de l'altitude des impluviums des réservoirs karstiques du Jura et du Vaucluse (18 oxygen contents according to the elevation of infiltration areas in karstic aquifers in the Jura and Vaucluse regions). In: Water resources in mountainous regions, vol 1 (in French). 22nd Congress of IAH, 1990, Lusanne, pp 331-338

Celle-Jeanton H, Emblanch C, Mudry J, Charmoille A (2003) Contribution of time tracers (Mg2+, TOC, 13C, NO3-) to understand the role of the unsaturated zone: a case study-karst aquifers in the Doubs Valley, eastern France. Geophys Res Lett 30(6)1322

Chalumeau A (2000) Fonctionnement hydrogéologique des exploitations de lignite du bassin de Fuveau (Hydrogeological behavior of lignite exploitations in the Fuveau basin). PhD Thesis, University of Franche-Comté, France 
Chanut JP (1976) Hydrogéologie des massifs Jura-crétacés et du Trias du S.W. varois (Hydrogeology of Jurassic, Cretaceous and Triassic mountains in the SW Var region). PhD Thesis, University of Provence, France

Cova R, Durozoy G (1980) Carte hydrogéologique du Var et notice, échelle 1/200 000ème (Hydrogeological map of the Var region with explanatory note, scale 1/200,000). Bureau de Recherches Géologique et Minière, Orléans

Dufresne DP, Drake CW (1999) Regional groundwater flow model construction and wellfield site selection in a karst area, Lake City, Florida. Eng Geol 52:129-139

Eisenlohr L (1996) Variabilité des réponses naturelles des aquifères karstiques. De l'identification de la réponse globale vers la connaissance de la structure de l'aquifère (Variability of natural responses of karstic aquifers: from the determination of the response to the knowledge of the structure of the aquifer.) PhD Thesis, University of Neuchâtel, Switzerland

Eisenlohr L, Bouzelboudjen M, Kiraly L, Rossier Y (1997) Numerical versus statistical modelling of natural response of a karst hydrogeological system. J Hydrol 202:244-262

Emblanch C (1997) Les équilibres chimiques et isotopiques du carbone dans les aquifères karstiques: étude en région méditerranéenne de montagne sur le bassin expérimental de la Fontaine de Vaucluse (Chemical and isotopic balances of carbon in karstic aquifers, investigation in Mediterranean mountainous region, experimental basin of the Fontaine de Vaucluse). $\mathrm{PhD}$

Thesis, University of d'Avignon et des Pays de Vaucluse, France Emblanch C, Blavoux B, Puig JM (1998) Dissolved organic carbon of infiltration within the autogenic karst hydrosystem. Geophys Res Lett 25(9):1459-1462

Emily A (2000) Recharge et fonctionnement d'un aquifère karstique tectoniquement compartimenté: exemple des écailles subalpine de l'arc de Nice (Alpes Maritimes) (Recharge and behavior of a tectonic compartmentalized karstic aquifer: example of subalpine thrusts in the Nice mountain range, Maritime Alps). PhD Thesis, University of Franche-Comté, France Fairchild IJ, Borsato A, Tooth AF, Frisia S, Hawkesworth CJ, Huang Y, McDermott F, Spiro B (2000) Controls on trace element ( $\mathrm{Sr}-\mathrm{Mg}$ ) compositions of carbonate cave waters: implications for speleothem climatic records. Chem Geol 166:255269

Fontes JC (1976) Isotopes du milieu et cycles des eaux naturelles: quelques aspects (Isotopes and cycles of natural water: some aspects). PhD Thesis, Pierre et Marie Curie University, Paris VI, France

Gdalia L (1980) Application d'un modèle conceptuel à plusieurs aquifères karstiques de la bordure méditerranéenne française, correspondance entre les paramètres du modèle et les caractères physiques des bassins versants (Application of a conceptual model to several karstic aquifers in French Mediterranean region, relationship between the model parameters and the physical data of the infiltration areas). PhD Thesis, University of Sciences and Techniques du Languedoc, France

Gouvernet C (1963) Structure de la région toulonnaise. Mémoire explicatif de la carte géologique (Structure of the Toulon area: memoir of the geological map of France). Ministère de l'industrie

Gouvernet C (1969) Carte géologique de Toulon et notice au 1/ 50000ème (Geological map of Toulon with explanatory note). Bureau de Recherches Géologique et Minières, Orléans

Guglielmi Y, Mudry J, Blavoux B (1998) Estimation of the water balance of alluvial aquifers in region of high isotopic contrast: an example from southeastern France. J Hydrol 210:106-115, Elsevier, Amsterdam

Lamarque T, Maurel P (2000) Projet Spélé-Eau à Siou Blanc, Compte rendu général des opérations 1993-2000 (Spélé-Eau project in Siou Blanc, general report of the investigation of 1993-2000). Comité départemental de spéléologie du Var. Toulon

Lastennet R (1994) Rôle de la zone non saturée dans le fonctionnement des aquifères karstiques- approche par l'étude physicochimique et isotopique du signal d'entrée et des exutoires du massif du Ventoux (Vaucluse) (Role of the unsaturated zone on karstic aquifer behavior: physical, chemical and isotopic approaches of input signal and discharge system of the Ventoux massif, Vaucluse). PhD Thesis, University of Avignon et des pays du Vaucluse, France

Laty AM (1981) Ressources en eaux des karsts méditerranéens français, essai de synthèse (Water resources of French Mediterranean karsts: synthesis). PhD Thesis, University of Languedoc, France

Lee ES, Krothe NC (2001) A four-component mixing model for water in a karst terrain in south-central Indiana, USA: using solute concentration and stable isotopes as tracers. Chem Geol 179:129-143

Lopez-Chicano M, Bouamama M, Vallejos A, Pulido-Bosch A (2001) Factors which determine the hydrogeochemical behavior of karstic springs: a case study from the Betic Cordilleras, Spain. Appl Geochem 16:1179-1192

Mangin A (1975) Contribution à l'étude hydrodynamique des aquifères karstiques (Contribution of hydrodynamic study to karstic aquifer studies). PhD Thesis, University of Dijon, France

Martin JB, Dean RW (2001) Exchange of water between conduits and matrix in the Floridan aquifer. Chem Geol 179:145165

McDonald MG, Harbaugh AW (1988) MODFLOW, Packages reference manual, Waterloo Hydrogeologic, Waterloo, Canada Mudry J (1987) Apport du traçage physico-chimique naturel à la connaissance hydrocinématique des aquifères carbonatés (Contribution of the physical and chemical natural tracers to the hydrodynamic knowledge of the carbonated aquifers). $\mathrm{PhD}$ Thesis, University of Franche Comté, Basancon, France Hydrogeology Journal DOI 10.1007/s10040-006-0044-1

Mudry J, Lastennet R, Puig JM, Blavoux B (1994) Use of natural tracing to understand how an aquifer works. In: Crampon N, Bakalowicz M (eds) Basic and applied hydrogeological research in French karstic areas. Montpellier,

France, pp 27-53 Mudry J, Charmoille A, Robbe N, Bertrand C, Batiot C, Emblanch C, and Mettetal JP (2002) Use of hydrogeochemistry to display a present recharge of confined karst aquifers: case study of the Doubs Valley, Jura Mountains, eastern France. In: Carrasco F, Duran JJ, Andreo B (eds) Karst and environment, Fundacion Cueva de Nerja, Malaga, pp 123-129

Olivier JM (1997) Principal components analysis. Software instructions for ADE4, CNRS, Paris

Perrin J, Jeannin PY, Zwahlen F (2003) Epikarst storage in a karst aquifer: a conceptual model based on isotopic data, Milandre test site, Switzerland. J Hydrol 279:106-124

Petelet E, Luck JM, Ben Othman D, Negrel P, and Aquilina L (1998) Geochemistry and water dynamics of a medium-sized watershed: 1. Organisation of the different water reservoirs as constrained by $\mathrm{Sr}$ isotopes, major and trace elements. Chem 
Geol 150:63-83

Plagnes V (2000) Structure et fonctionnement des aquifères karstiques, caractérisation par la géochimie des eaux (Structure and behavior of karstic aquifers, characterization by hydrogeochemistry). PhD Thesis, University of Montpellier, Bureau de Recherches Géologique et Minières, Orléans

Puig JM (1987) Le système karstique de la Fontaine de Vaucluse (The karstic system of the Vaucluse spring). PhD Thesis, University of Avignon et des pays de Vaucluse, France

Razafindrakoto S (1988) Teneurs en isotopes stables des précipitations et des eaux souterraines en France et leurs variations (Stable isotope contents in rainfall and groundwater in France and their variations). PhD Thesis, University of Avignon, France

Reynaud A (2000) Fonctionnement d'un aquifère karstique décollé sur une semelle de Trias évaporitique, exemple du massif du mont Vial (Arc de Castellane, Alpes-Maritimes) (Behavior of a karstic aquifer with an evaporitic sole,

example of the mount Vial massif, Castellane region, southeastern France). PhD Thesis, University of Franche Comté, Basancon, France

Scanlon BR, Mace RE, Barrett ME, Smith B (2003) Can we simulate regional groundwater flow in a karst system using equivalent porous media models? Case study, Barton Springs Edwards aquifer, USA. J Hydrol 276:137-158

Vandenschrick G, Van Wesemael B, Frot E, Pulido-Bosch A, Molina L, Stievenard M, Souchez R (2002) Using stable isotope analysis (D-18O) to characterize the regional hydrology of the Sierra de Gador, southeast Spain. J Hydrol 265: 43-55

Vernet M, Vernet B (1981) Essai de discrimination par méthode isotopique de l'origine des eaux de systèmes karstiques, application aux karsts continentaux et littoraux de Basse Provence (Discrimination of the karstic water origin with isotopic methods, application to the continental and littoral karsts in the Provence region). PhD Thesis, University of Provence, France

White WB (2002) Karst hydrology: recent developments and open questions. Environ Geol 65:85-105 


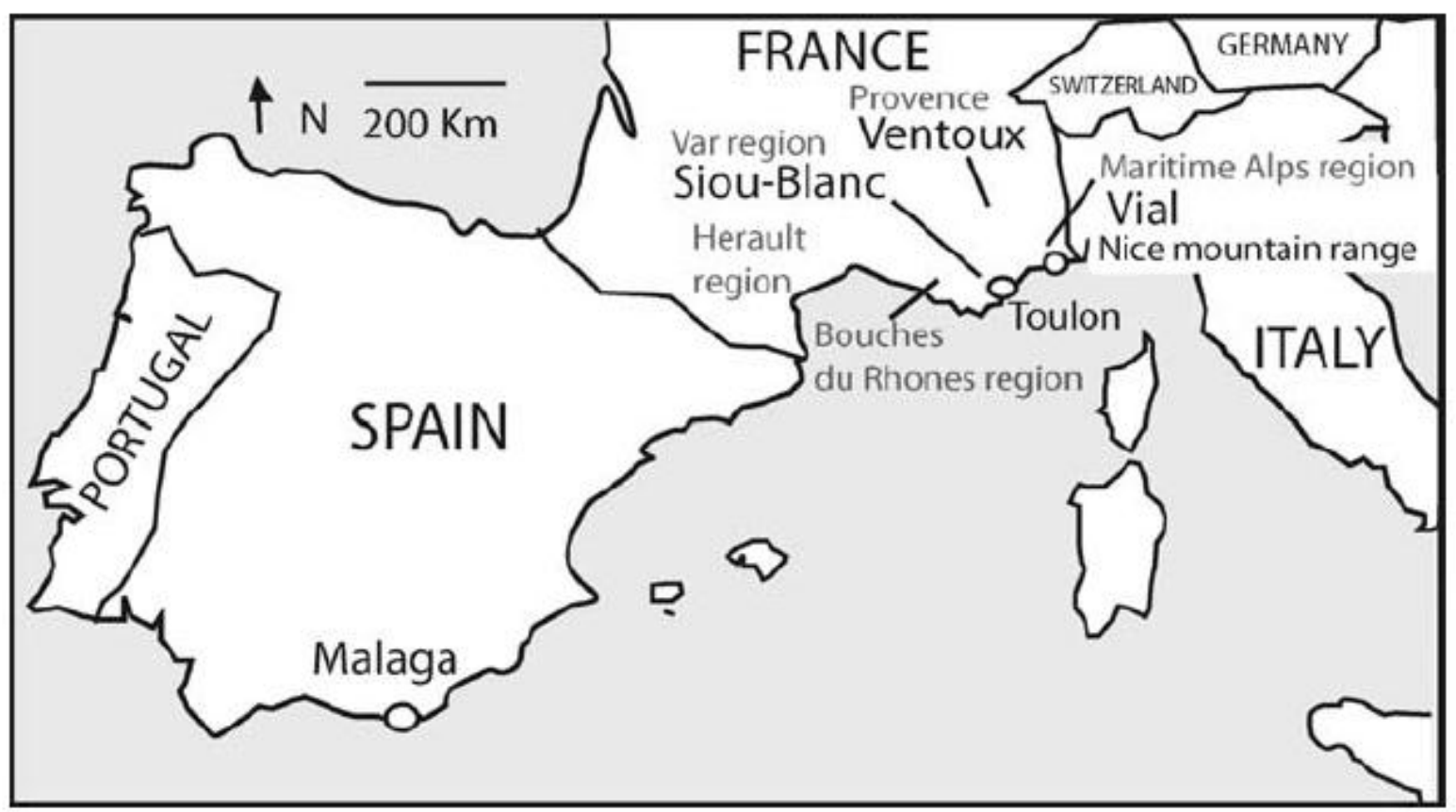

Fig. 1 Geographical location of the karsts used to build a conceptual model of Mediterranean karst Table 1 Atmospheric parameters versus elevation in a Mediterranean climate

\begin{tabular}{|c|c|c|c|c|c|}
\hline $\begin{array}{l}\text { Atmospheric parameters in } \\
\text { Mediterranean locations }\end{array}$ & Slope & Intercept & $\begin{array}{l}\text { Correlation } \\
r\end{array}$ & $\begin{array}{l}\text { Number of } \\
\text { measurements }\end{array}$ & References \\
\hline \multicolumn{6}{|l|}{ Temperature } \\
\hline Provence & -0.00641 & 14.53 & -0.993 & 28 & Mudry 1987 \\
\hline Maritime Alps & -0.0053 & 15.2508 & -0.99 & 7 & Reynaud 2000 \\
\hline Ventoux & -0.0052 & 13.95 & -0.92 & 14 & Puig 1987 \\
\hline \multicolumn{6}{|l|}{ Rainfall value } \\
\hline $\begin{array}{c}\text { Provence, Maritimes Alps, } \\
\text { Var, Bouches du Rhone }\end{array}$ & 0.498 & 713.8 & 0.686 & 28 & Mudry 1987 \\
\hline Provence & 0.55 & & & & Blavoux and Mudry 1990 \\
\hline $\begin{array}{l}\text { Var, Herault, Bouches du } \\
\text { Rhone, Maritime Alps, } \\
\text { Provence }\end{array}$ & 0.57 & 683.9 & 0.89 & 33 & $\begin{array}{l}\text { Vernet and Vernet 1981; Fairchild et al. 2000; } \\
\text { Lastennet 1994; Laty 1981; Reynaud 2000; } \\
\text { Emily 2000 }\end{array}$ \\
\hline $\begin{array}{l}\text { Malaga (Spain ) } \\
\delta^{18} \mathrm{O}\end{array}$ & 0.43 & 582.1 & 0.43 & & Andreo 1996 \\
\hline $\begin{array}{l}\text { Maritime Alps, log } \\
\text { (elevation) }\end{array}$ & -3.62 & 1.923 & 0.92 & 34 & Guglielmi et al. 1998 \\
\hline
\end{tabular}

Table 1 Atmospheric parameters versus elevation in a Mediterranean climate 


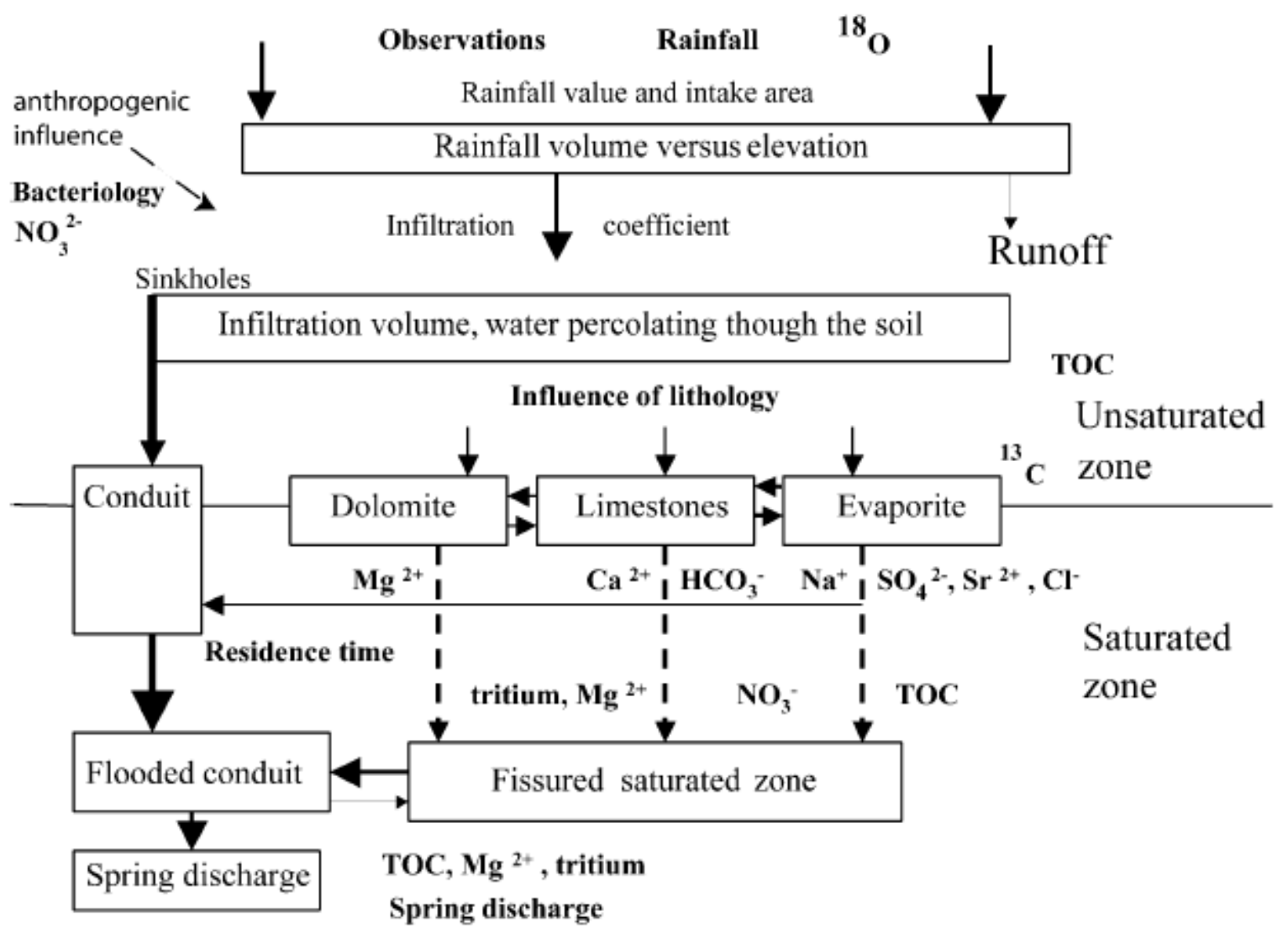

Fig. 2 Conceptual model of a Mediterranean karst system shows functioning of karst components and appropriate model descriptors (shown in bold) useful for understanding the system. Text in black is for the descripton 


\begin{tabular}{|c|c|c|c|c|c|c|c|c|c|c|c|c|c|c|c|c|c|c|c|c|}
\hline $\begin{array}{l}\text { Site } \\
\text { number }\end{array}$ & Spring name & $\begin{array}{l}\text { Elevation } \\
\text { mas.1. }\end{array}$ & $\begin{array}{l}Q \text { low } \\
\text { waster } \\
(\mathrm{L} / \mathrm{s})\end{array}$ & $\begin{array}{l}Q Q \\
\text { flood } \\
(\mathrm{L} / \mathrm{s})\end{array}$ & $\begin{array}{l}\text { Teny. } \\
{ }^{\circ} \mathrm{C}\end{array}$ & $\begin{array}{l}\text { Cond. } \\
\text { wisem }\end{array}$ & $\mathrm{pH}$ & $\mathrm{HCO}_{3}^{-}$ & $\mathrm{F}$ & $\mathrm{CT}$ & $\mathrm{NO}_{3}^{-}$ & $\mathrm{SO}_{4}^{2-}$ & $\begin{array}{l}\mathrm{Mg}^{2+} \\
\mathrm{mg} / \mathrm{L}\end{array}$ & $\mathrm{Na}^{+}$ & $\mathrm{K}^{+}$ & $\mathrm{s}^{2+}$ & $\mathrm{Ca}^{2+}$ & TOC & $\begin{array}{l}100 \\
\%\end{array}$ & $\begin{array}{l}\text { B } \\
\%\end{array}$ \\
\hline$\overline{1}$ & Trians & 335 & 0.5 & & 12.2 & 512 & 7.6 & 318 & 0.5 & 75 & 1.8 & 60 & 10.6 & 3.9 & 05 & 0.1 & 95.6 & 10 & -6.75 & 1.5 \\
\hline 2 & Font Gryou & 330 & 5.6 & & 124 & 591 & 75 & 378 & 0.5 & 7.4 & 16 & 7.0 & 280 & 4.1 & 0.4 & 00 & 86.8 & 0.9 & -6.98 & 0.6 \\
\hline 3 & Rampins & 250 & 4.1 & 7,300 & 11.0 & 522 & 8.1 & 310 & 0.1 & 8.7 & 6.7 & 193 & 250 & 5.1 & 0.7 & a.1 & 77.0 & 10 & -6.70 & 1.6 \\
\hline 4 & Gavadn I & 290 & $i$ & 100 & i2.5 & 530 & 80 & 355 & $0 . i$ & 6.7 & 03 & 66 & 305 & 3.7 & 03 & 0.0 & 65.2 & 0.7 & -6.98 & -32 \\
\hline 5 & Gavadn 2 & 2200 & 3 & & 124 & 567 & 7.6 & 373 & 0.1 & 7.1 & 0.0 & 9.1 & 345 & 3.9 & 0.4 & 00 & 77.8 & 0.7 & -6.93 & 1.6 \\
\hline 6 & $\begin{array}{l}\text { Saint } \\
\text { Mathieg }\end{array}$ & 145 & & & 14.1 & 781 & 7.7 & 316 & 0.4 & 10.7 & 1.8 & 164.1 & 275 & 5.8 & 1.1 & 1.0 & 159.0 & 0.8 & -6.82 & 7.2 \\
\hline 7 & Lxanal & 190 & 1 & 120 & 13.8 & 550 & 76 & 332 & 0.1 & 89 & 0.6 & 133 & 295 & 6.0 & 0.7 & 0.2 & 79.2 & 0.9 & -7.13 & 4.2 \\
\hline 8 & Rouvière & 170 & 0 & 130 & 14.7 & 560 & 75 & 364 & 0.1 & 10.4 & 24 & 160 & 230 & 4.8 & 0.6 & 0.1 & 84.4 & 09 & -6.61 & -3.2 \\
\hline 9 & Foat da Thón & 104 & 5 & 115 & 14.8 & 622 & 75 & 300 & 03 & 11.4 & 27 & 71.4 & 235 & 6.1 & 1.0 & as & 97.8 & 0.7 & -6.71 & 1.2 \\
\hline 10 & Valany & 200 & 5 & 500 & 10.7 & 550 & 75 & 325 & 0.1 & 132 & 29 & 19.7 & 18.5 & 6.4 & 0.9 & 0.1 & 89.0 & & -5.83 & 0.2 \\
\hline 11 & Les Genets & 83 & 4 & & 13.4 & 833 & 7.7 & 289 & 0.4 & 232 & 3.1 & 200.7 & 29.0 & 15.1 & 1.4 & 10 & 159.0 & 0.5 & -7.05 & 6.0 \\
\hline 12 & Werotte & 110 & 0.5 & 5 & 14.2 & 568 & 75 & 337 & 0.5 & 140 & 22 & 43.7 & 205 & 90 & 1.0 & 0.9 & 85.6 & 0.6 & -7.16 & -46 \\
\hline 13 & $\begin{array}{l}\text { Foux } \\
d^{\prime} \text { 'Ayou }\end{array}$ & 160 & & & 126 & 947 & 7.6 & 289 & 03 & 255 & 95 & 260.7 & 23.8 & 140 & 4.8 & 10 & 194.0 & 0.7 & -7.09 & 5,3 \\
\hline 14 & Reganas & 145 & 0.25 & 10 & 155 & 676 & 7.4 & 305 & 0.0 & 26.5 & 39 & 843 & 20.8 & 11.2 & 1.1 & 13 & 137.0 & 0.8 & -7.37 & 8.5 \\
\hline 15 & $\begin{array}{c}\text { Maire des } \\
\text { eanx }\end{array}$ & 130 & 10 & 500 & 15.6 & 627 & 75 & 346 & 0.6 & 7.8 & 40 & 19.1 & 18.8 & 7.6 & 0.9 & 0.2 & 105.8 & 0.8 & -6.65 & 5.3 \\
\hline 16 & $\begin{array}{c}\text { Matteoli obs. } \\
\text { borehole }\end{array}$ & 120 & & & 169 & 958 & 7.7 & 377 & 0.8 & 30.1 & 185 & 168.2 & 250 & 13.9 & 13 & 12 & 190.0 & & -6.54 & 5.4 \\
\hline 17 & La Rigelle & 250 & 0.25 & 3 & 14.3 & 572 & 7.7 & 337 & 0.1 & 12.4 & 5.7 & 17.2 & 28 & 5.4 & 0.6 & 0.1 & 147.0 & 0.7 & -6.49 & 10.7 \\
\hline 18 & $\begin{array}{l}\text { Rodallac } \\
\text { obs. }\end{array}$ & 5 & & 35 & 18.8 & 938 & 75 & 316 & 0.0 & 78.2 & 37.9 & 94.1 & 20.7 & 40.5 & 39 & 0.4 & 158.0 & 0.6 & -6.58 & 7.1 \\
\hline 19 & Saint Antoine & 20 & 50 & 1250 & 153 & 578 & 78 & 284 & 0.4 & 18.5 & 95 & 45.8 & 149 & 105 & 13 & 0.3 & 96.6 & 0.7 & -6.72 & 1.5 \\
\hline 20 & $\begin{array}{l}\text { CEO's } \\
\text { drilling }\end{array}$ & 90 & & & 15.8 & 434 & 7.8 & 224 & 0.2 & 10.6 & 24 & 23.8 & 105 & 4.7 & 13 & 0.1 & 73.4 & 23 & -5.78 & 2.2 \\
\hline 21 & Ragas & 90 & 1 & 115 & 14.2 & 422 & 8.2 & 249 & 0.1 & 8.8 & 3.7 & 13.7 & 10.2 & 4.7 & 0.3 & 0.1 & 82.4 & 09 & -6.80 & 4.6 \\
\hline 22 & $\begin{array}{l}\text { Baumes de } \\
\text { dardemos }\end{array}$ & 24 & 4 & 31 & 16.0 & 637 & 79 & 307 & 0.3 & 23.6 & 13.6 & 46.2 & 159 & 12.4 & 1.2 & 0.3 & 1100 & 0.7 & -6.44 & 3.1 \\
\hline 23 & $\begin{array}{l}\text { Cappage } \\
\text { d'Evenos }\end{array}$ & 260 & & & 133 & 733 & 72 & 420 & 0.0 & 24.1 & 39 & 25.2 & 6.5 & 125 & 0.7 & 0.4 & 173.0 & & -6.73 & 8.8 \\
\hline 24 & Sla Reppe & 75 & & & 14.8 & 504 & 72 & 290 & 0.1 & 21.4 & 19 & 25.9 & 40 & 13.7 & 12 & 05 & 197.0 & 10 & -7.78 & 29.0 \\
\hline 25 & Dnid's & 290 & 0.25 & 5 & 130 & 715 & 7.8 & 406 & 0.0 & 24.5 & 39 & 25.8 & 6.5 & 12.5 & 0.7 & 0.4 & 169.0 & 0.7 & -6.70 & 9.1 \\
\hline 26 & $\begin{array}{l}\text { Spping } \\
\text { Trou de h } \\
\text { Bombe }\end{array}$ & 100 & 0 & 48 & 146 & 525 & 7.4 & 270 & 0.6 & 24.7 & 1.6 & 27.0 & 5.1 & 159 & 10 & 03 & 95.4 & 10 & -837 & 13 \\
\hline 27 & Mascarco & $6 !$ & 23 & 152 & 16.1 & 529 & 7.6 & 277 & 0.5 & 20.9 & 1.5 & 23.1 & 4.4 & 133 & 0.8 & 03 & 99.4 & 0.9 & -7.77 & 22 \\
\hline 28 & $\begin{array}{l}\text { Maire des } \\
\text { Fontaines }\end{array}$ & 50 & 1 & 30 & 14.1 & 563 & 72 & 312 & 0.1 & 14.7 & 4.7 & 215 & 6.6 & 0.8 & 0.9 & 02 & 1082 & 0.9 & -6.69 & -0.6 \\
\hline 29 & Bomefort & 60 & 0 & 15 & 153 & $72 !$ & 7.4 & 364 & 0.2 & $3 ! 3$ & 13.8 & 34.6 & 235 & 20.7 & 0.8 & 0.3 & 107.6 & 0.6 & -6.81 & 23 \\
\hline 30 & $\begin{array}{c}\text { Messcoier } \\
\text { drilling }\end{array}$ & 20 & & & 195 & 2040 & 73 & 407 & 0.0 & 47.9 & 8.3 & 646.0 & 32.0 & 265 & 1.1 & 3.8 & 509.0 & 0.8 & -6.25 & 14.8 \\
\hline 31 & Gapeas & 315 & 2 & 5 & 13.4 & 430 & 7.7 & $25 !$ & 0.1 & 7.0 & 1.3 & 10.8 & 26.0 & 4.1 & 05 & 0.1 & 524 & 0.4 & -7.71 & 26 \\
\hline 32 & $\begin{array}{l}\text { Foot de } \\
\text { l'Eorave }\end{array}$ & 320 & 0 & 1 & 11.4 & 616 & 7.4 & 359 & 0.1 & 6.3 & 0.1 & 40.6 & 22.9 & 3.4 & 0.4 & 03 & 1060 & 0.6 & -7.05 & 22 \\
\hline 33 & $\begin{array}{l}\text { Motrisux le } \\
\text { vieux }\end{array}$ & 290 & & 500 & 122 & 510 & 7.6 & 317 & 0.1 & 5.8 & 0.5 & 9.4 & 28.5 & 32 & 0.4 & 0.0 & 66.4 & 0.5 & -752 & 0.8 \\
\hline 34 & $\begin{array}{c}\text { Mootrieux le } \\
\text { Jeune ! }\end{array}$ & 340 & 1 & 24 & 11.9 & 468 & 7.8 & 295 & 0.1 & 5.6 & 0.4 & 6.6 & 27.0 & 32 & 0.3 & 0.0 & 59.8 & 0.4 & -737 & 0.6 \\
\hline
\end{tabular}

Table 2 Natural chemical tests undertaken on the Siou-Blanc Plateau springs in June 2002 (analyzed at the Geosciences Laboratory, Besancon). Spring sites are located in Fig. 3 


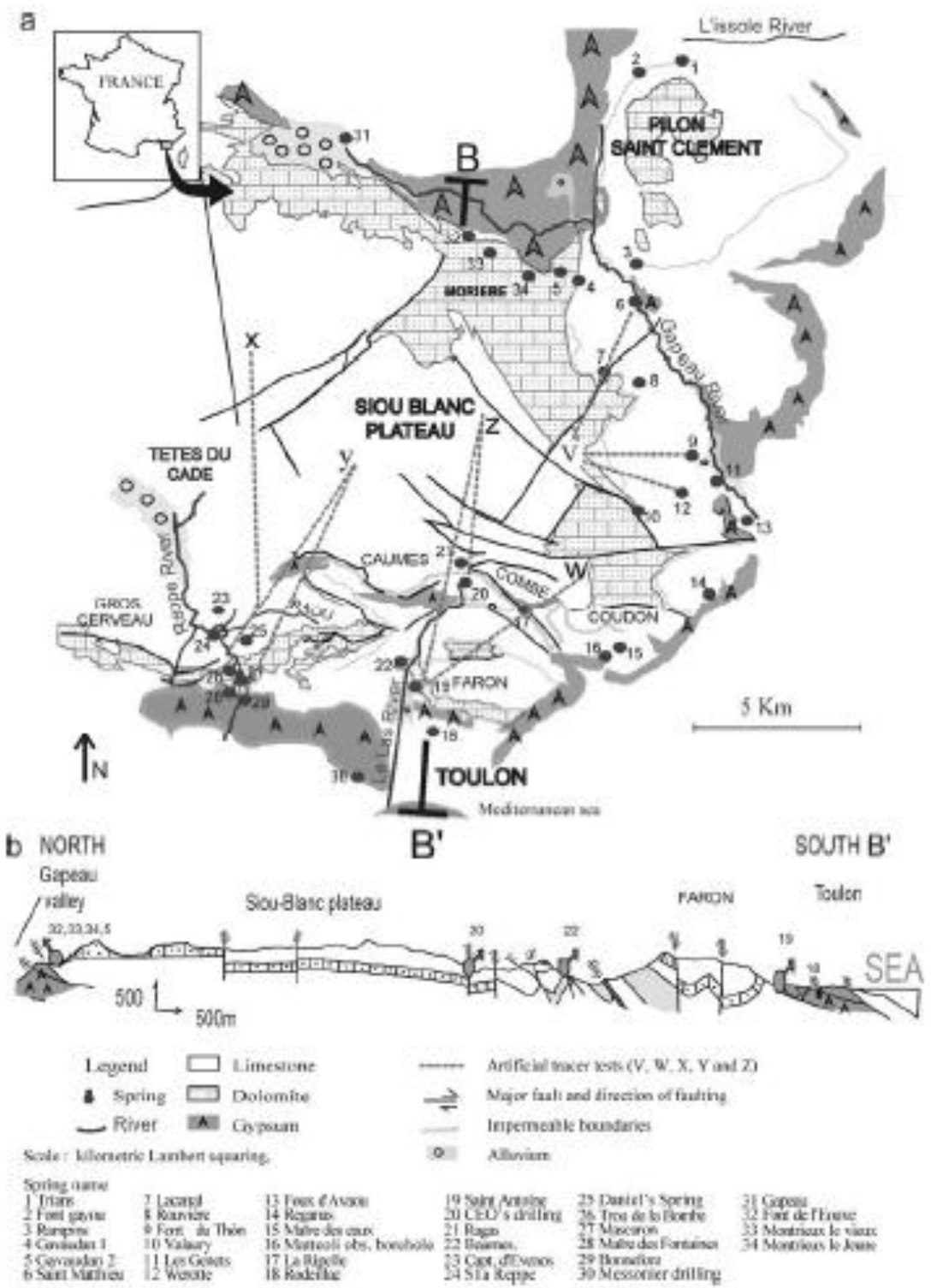

Fig. 3 a Hydrogeological map and b cross section of the Siou-Blanc Plateau and b cross section of the Siou-Blanc Plateau

\begin{tabular}{|c|c|c|c|c|}
\hline Input locations & $\begin{array}{l}\text { Map code } \\
\text { Fig. } 3\end{array}$ & $\begin{array}{l}\text { Mean } \\
\text { velocity } \\
(v \mathrm{~m} / \mathrm{h})\end{array}$ & Tracer type & Output springs \\
\hline $\begin{array}{l}\text { Aven de La } \\
\text { solitude }\end{array}$ & $\mathrm{Z}$ & $15<v<20$ & Fluorescence & Ragas 21, St Antoine 19 \\
\hline $\begin{array}{l}\text { Abime de } \\
\text { Maramoye }\end{array}$ & $\mathrm{X}$ & $3<v<4$ & $\begin{array}{l}\text { Rhodamine } \\
\text { B }\end{array}$ & $\begin{array}{l}\text { Bonnefont 29, Trou de la Bombe 26, Mascaron 27, Maire des } \\
\text { Fontaines } 28\end{array}$ \\
\hline Aven des Polonais & $\mathrm{V}$ & $10<v<18$ & $\begin{array}{l}\text { Rhodamine } \\
\text { B }\end{array}$ & Rouvière 8 , Font du Thon 9, St Mathieu 6 \\
\hline Aven Gauthier & Y & $3.4<v<4.1$ & Fluorescence & $\begin{array}{l}\text { Bonnefont 29, Trou de la Bombe 26, Mascaron 27, Maire des } \\
\text { Fontaines } 28\end{array}$ \\
\hline Aven du Caniveau & W & 7 & Lithium & St Antoine 19 \\
\hline
\end{tabular}

Table 3 Artificial tracer tests undertaken by Lamarque et al. (2000). Tracer test identifiers are shown in Fig. 3

Input locations Map code 


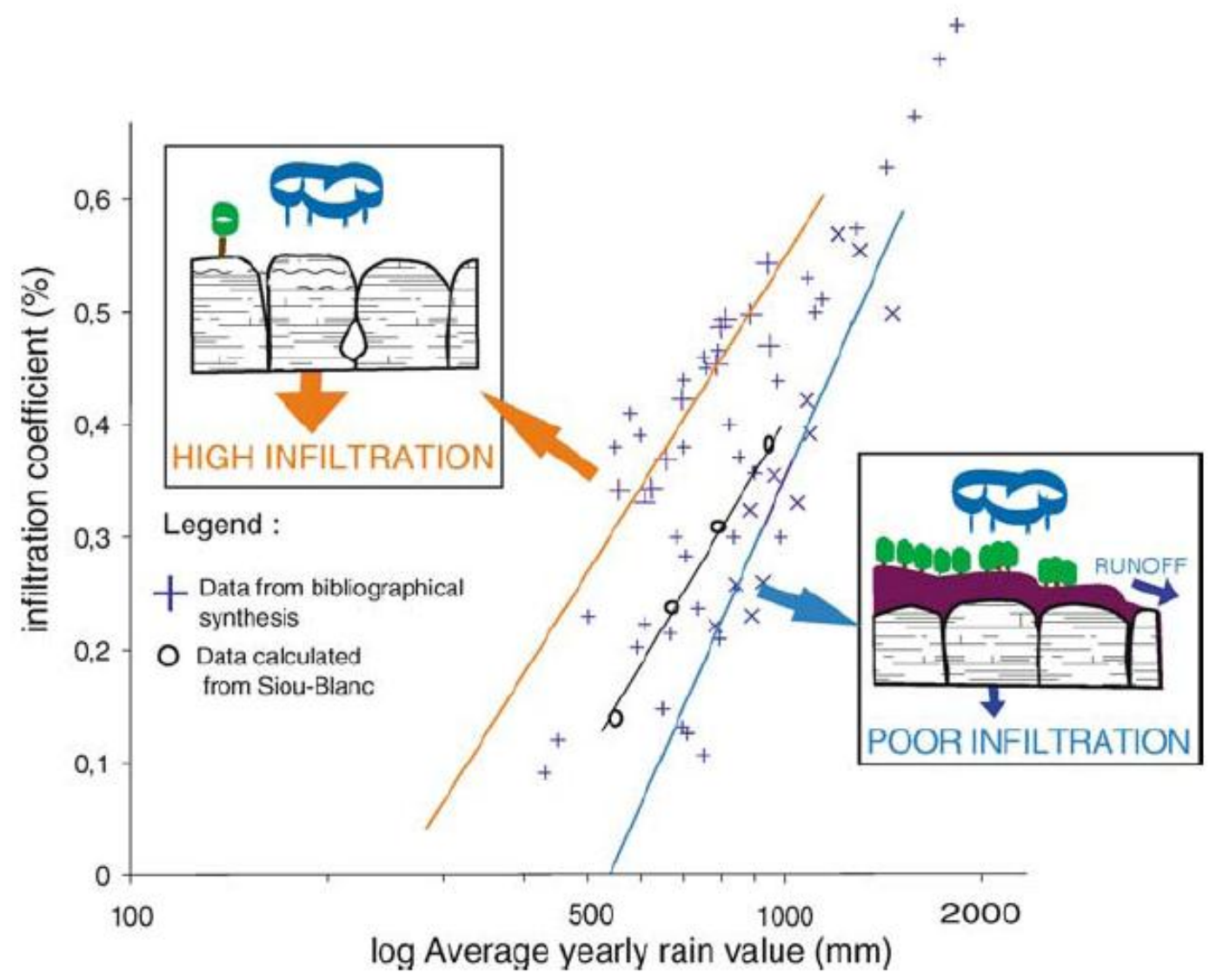

Fig. 4 Infiltration coefficient versus rainfall value. Data are from Cova and Durozoy (1980), Laty 1981, Vernet and Vernet (1981), Puig (1987), Andreo (1996) and Reynaud (2000) and calculations are from the Pilon Saint Clément recharge area 


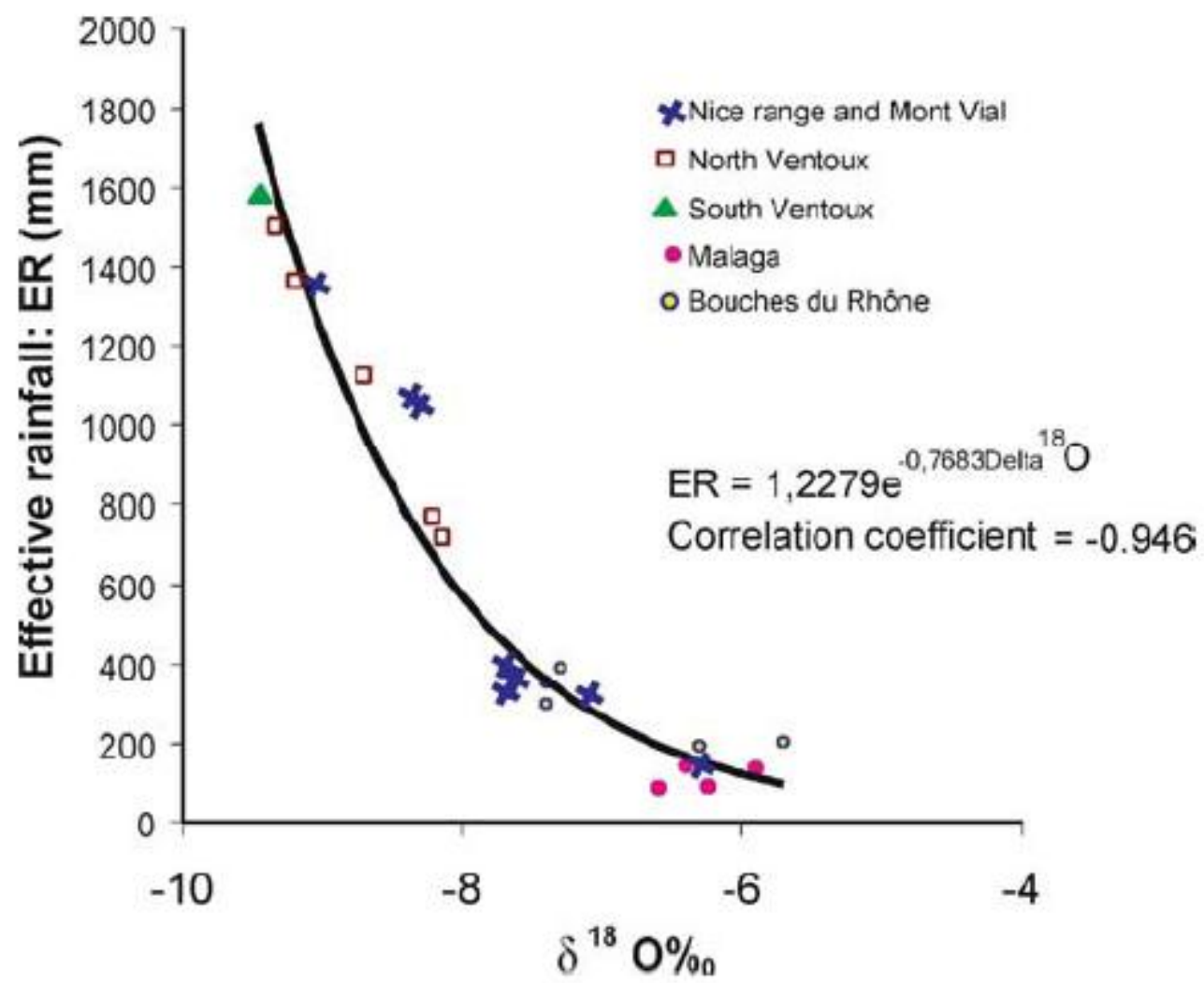

Fig. 5 Effective rainfall versus $\delta_{18 O}$ content in rainfall. Data are from Vernet and Vernet (1981), Puig (1987), Andreo (1996) and Reynaud (2000)

a

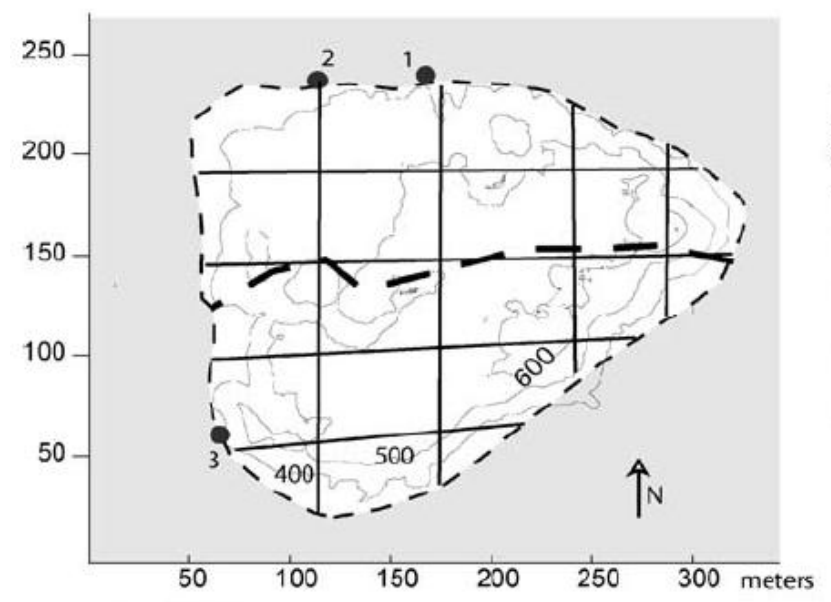

- $\quad$ Spring

Impermeable boundary

$\square$ Permeable limestone

- Fracture

- - Watershed, calculated with the springs in steady state Elevation (masl)

\section{b}

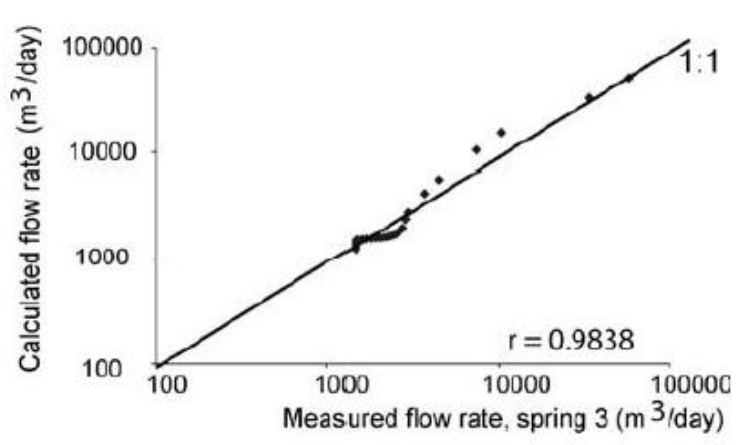

Choosed parameters

$\mathrm{Kl}=1 \mathrm{~m} / \mathrm{s}$ (Fracture permeability)

$\mathrm{K} 2=10^{-6} \mathrm{~m} / \mathrm{s}$ (Matrix permeability)

Porosity $1=0.01 \%$

Porosity $2=0.05 \%$

Average infiltration coefficient $=0.21 \%$

Fig. 6 The Pilon Saint Clement model: a numerical determination of the watershed (steady state calculation, calibrated with low flow rate at the spring), and b chosen model parameters 
${ }^{18} \mathrm{O}=0.0053 \times$ elevation -3.25 (estimated with field data)

\begin{tabular}{ll}
\hline Infiltration gradient & Calculated $\delta^{18} \mathrm{O} \%$ \\
\hline $0 \mathrm{~mm} / 100 \mathrm{~m}$ & -6.05 \\
$2 \mathrm{~mm} / 100 \mathrm{~m}$ & -6.08 \\
$5 \mathrm{~mm} / 100 \mathrm{~m}$ & -6.36 \\
$10 \mathrm{~mm} / 100 \mathrm{~m}$ & -6.72 \\
$15 \mathrm{~mm} / 100 \mathrm{~m}$ & -7.05 \\
$\delta^{18} \mathrm{O}$ measured at the Rampins spring no. 3 & -6.7
\end{tabular}

Table 4 Calibration of the numerical model with $\delta_{18} \mathrm{O}$ values calculated for different infiltration gradients ${ }_{18} \mathrm{O}=0.0053 \times$ elevation - 3.25 (estimated with field data) Infiltration gradient Calculated $\delta_{18} \mathrm{O} \%$

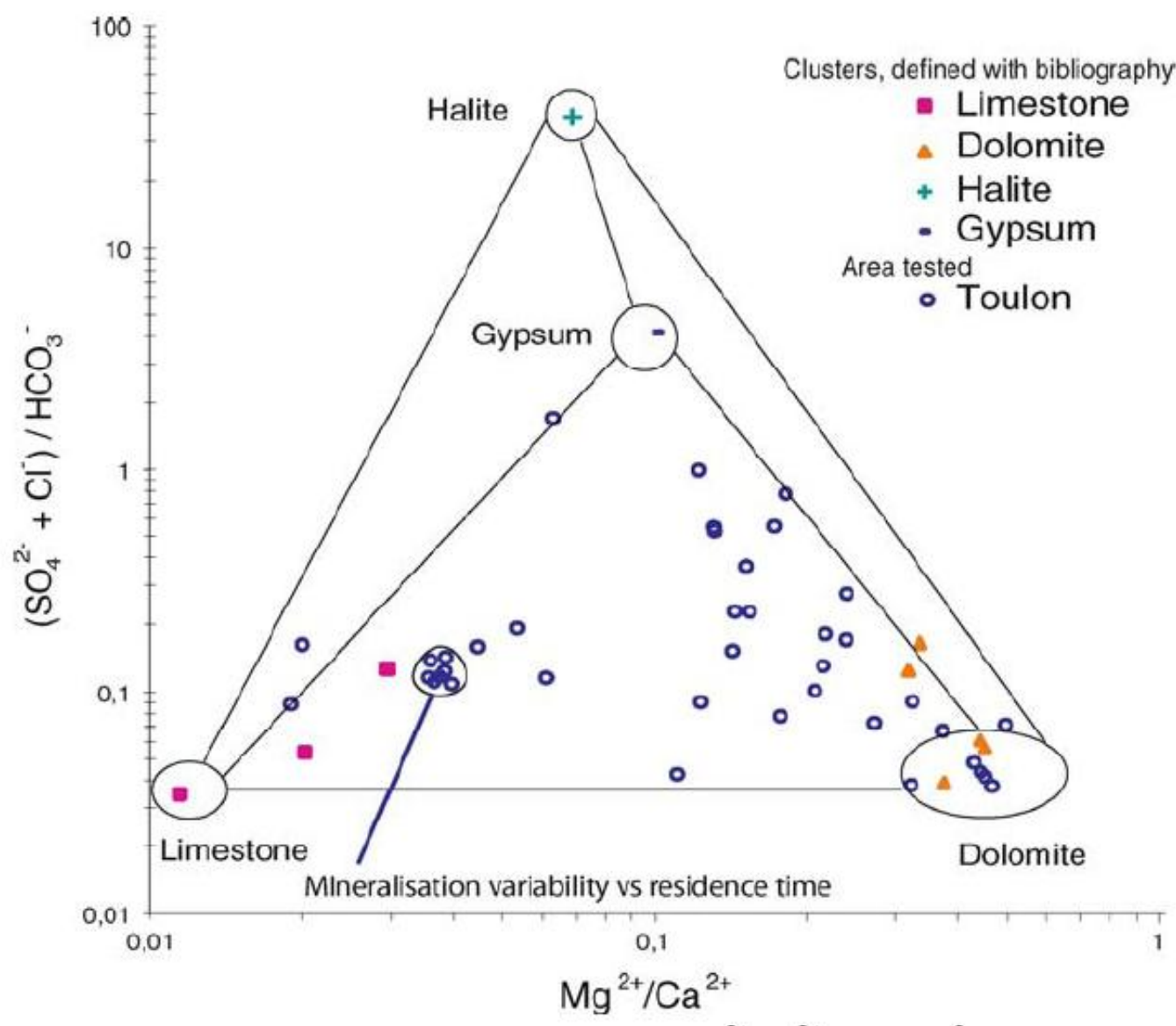

Fig. 7 Component mixture of karst water chemistry. Evolution of the ratio $\hat{\mathrm{Mg}}_{2+} / \mathrm{Ca} 2+$ and $\left(\mathrm{SO}_{4} 2+\mathrm{Cl}-\right) / \mathrm{HCO}_{3}$-. The clusters were built with data from Cova and Durozoy (1980), Laty (1981), Vernet and Vernet (1981), Puig (1987), Petelet et al. (1998), Emily (2000), Fairchild et al. (2000) and Reynaud (2000). The plotted data correspond to the Siou-Blanc spring measurements 


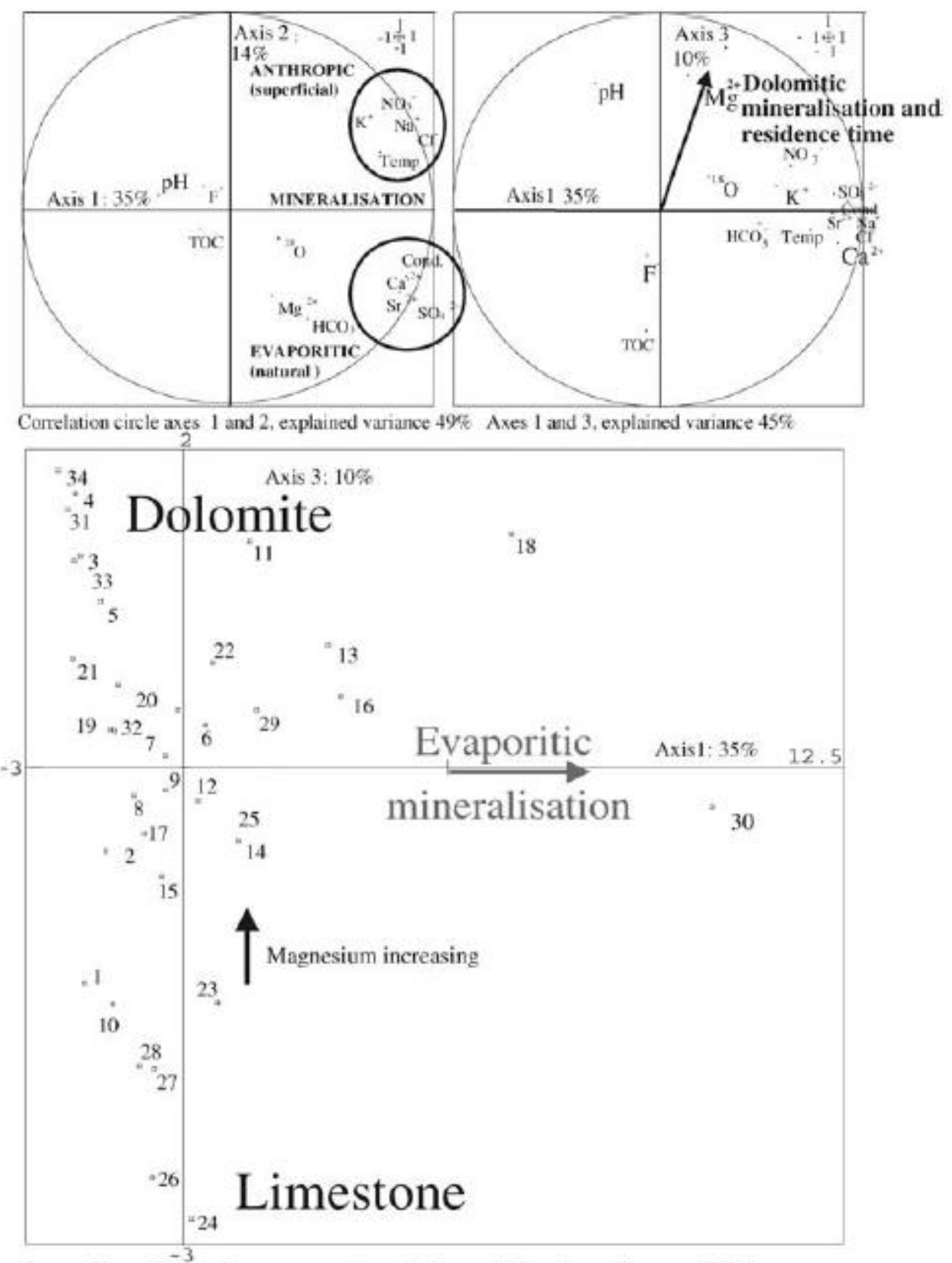

Sampling data along axes 1 and 3 explained variance $45 \%$

Fig. 8 Principal component analysis of water chemistry measurements at the Siou-Blanc springs 


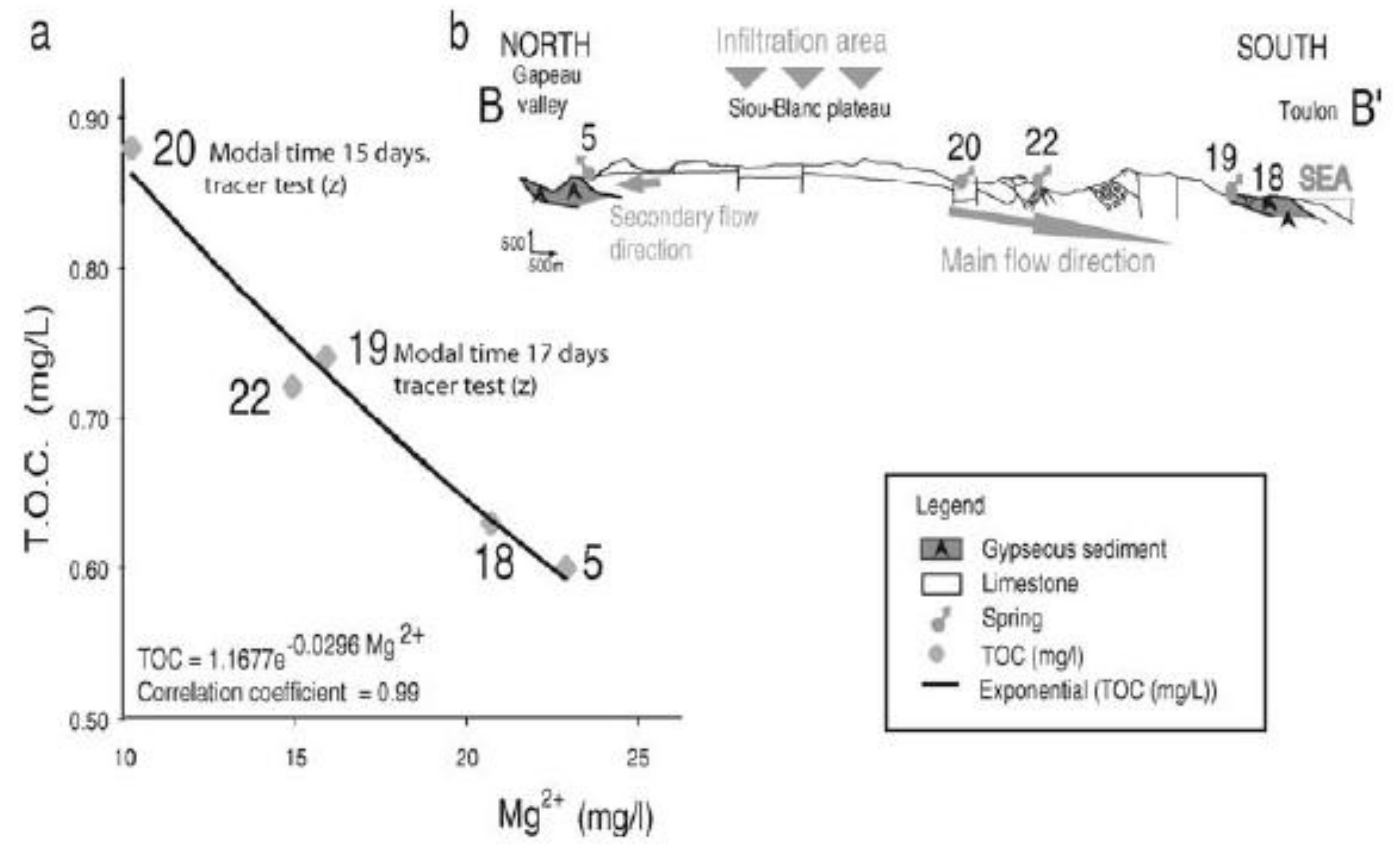

Fig. 9 a Total organic carbon measurements versus magnesium contents of the Siou-Blanc karst springs. b A schematic cross section shows the relationship between measurements and residence time across the Siou-Blanc Plateau 